Original Research

\title{
Implementasi Model PjBL terhadap Peningkatan Keterampilan Proses Sains dan Sikap IImiah Siswa Kelas VIII SMP
}

\author{
Anthony Firdaus ${ }^{1,{ }^{*}}$, Yula Miranda ${ }^{1}$, Soaloon M Sinaga ${ }^{1}$ \\ ${ }^{1}$ Program Studi Magister Pendidikan Biologi Program Pascasarjana Universitas Palangka Raya. Kampus UPR Tunjung Nyaho, \\ J. Yos Sudarso Palangka Raya, Indonesia, 73111 \\ * Korespondensi: Anthony Firdaus (Email: anthonyfirdaus548@gmail.com)
}

\begin{abstract}
It has been observed that the level of science process skills and students' scientific attitudes, to seome extent, has not been formed, so the learning activity process has been running in slow motion. This study aims to examine the impact of project based learning (PjBL model) on the improvement of students' science process skills (KPS) and scientific attitudes, especially on plant tissue lesson. A pretest-posttest research design was applied to two classes of 8th grade students of SMPN 9 Palangka Raya, namely class VIIIA as the treated group, and while VIIIb as the control class using conventional learning models. The instruments used were lesson plans, science process skills observation sheets, scientific attitude questionnaires, and a number of test questions for testing. The results show that $\mathrm{PjBL}$ can improve science process skills with an N-gain of 0.70 in treated group, which is classified as high category, and N-gain of 0.48 in the control class which is in the moderate category. The PjBL implementation does not improve scientific attitudes because the $\mathrm{N}$-gain value is 0.58 in the experimental class, quite similar to 0.32 point in the control class; both fall on moderate category.
\end{abstract}

Keywords

PjBL, project based learning, science process skills, student scientific attitudes, plant tissue

\section{PENDAhUluAN}

Berdasarkan hasil observasi pendahuluan yang dilakukan di SMP yang berada di kota Palangka Raya melalui kegiatan praktikum dalam pada pelaksaan KPS, indikator yang diamati antara lain adalah pengamatan dan pengklasifikasian masih berada dalam hasil yang kurang maksimal. Hal ini berpengaruh terhadap kegiatan proses dan hasil kegiatan praktikum yang tidak maksimal juga.

Masalah lain pada ranah sikap ilmiah yang ditemukan, pada saat praktikum siswa terlihat pasif dan tidak disiplin saat melakukan praktikum. Hal ini ditunjukkan saat siswa diminta untuk melakukan kegiatan praktikum masih banyak yang tidak mengikuti kegiatan praktikum dengan baik karena sibuk dengan teman lainnya. Berdasarkan dua permasalahan tersebut dapat dikatakan bahwa aspekaspek keterampilan proses sains seperti keterampilan mengamati, merencanakan, melakukan kegiatan, membuat kesimpulan dan mengkomunikasikan, dan aspek sikap ilmiah seperti sikap jujur, teliti, tanggung jawab, disiplin dan rasa ingin tahu juga belum tercapai secara optimal. Aspek keterampilan proses sains dan sikap ilmiah yang belum tercapai secara optimal akan menyebabkan pengetahuan yang diterima siswa kurang bermakna, karena siswa memperoleh pengetahuan bukan berasal dari penemuan atau pemberian pengalaman secara langsung. Oleh sebab itu, perlu dioptimalkan dengan kinerja siswa diantaranya melalui model PjBL.

Dengan menerapkan model PjBL maka kualitas yang telah dirancang dalam Kurikulum 2013 diharapkan dapat tercapai. Karena dengan menerapkan model PjBL, prinsip kegiatan pembelajaran dapat tercapai yaitu, (1) orientasi pada peserta didik; (2) mengembangkan kreativitas peserta didik; (3) menciptakan kondisi bebas dan menyenangkan; (4) bermuatan nilai, etika, estetika, logika, dan kines-tetika; (5) menyediakan pengalaman belajar yang bervariasi melalui penerapan berbagai strategi dan metode pembelajaran yang menyenangkan, kontekstual, efektif, efisien, dan bermakna walaupun waktu yang dialokasikan juga lebih lama. Akibatnya, kegiatan belajar dapat membantu para peserta didik dari awalnya tidak tahu menjadi tahu dan hasil pembelajaran dapat lebih optimal (Biggs, 2010). 
Materi jaringan tumbuhan merupakan salah satu materi yang mendukung model PjBL sehingga dipilih sebagai materi dalam penelitian. Karena dalam kegiatan pembelajaran pada materi jaringan tumbuhan siswa diminta mengamati dan mengidentifikasi struktur dan fungsi tumbuhan serta taknologi yang terinspirasi oleh struktur tumbuhan dan menyusun rencana dan melakukan percobaan berdasarkan hasil pengamatan. Peneliti menyimpulkan bahwa kegiatan pembelajaran tersebut sesuai dengan sintaks PjBL. Penelitian dilakukan di sekolah menengah pertama yaitu kelas 8 SMP karena telah melaksanakan Kurikulum 2013 IPA untuk SMP. Dalam kurikulum tersebut materi jaringan tumbuhan merupakan salah satu materi yg di ajarkan di kelas 8. Dan peneliti menyesuaikan indikator dan tujuan pembelajaran dengan judul penelitian.

Penelitian ini bertujuan untuk mengetahui pengaruh model pembelajaran berbasis proyek terhadap peningkatan keterampilan proses sains dan sikap ilmiah siswa.

\section{METODOLOGI}

\subsection{Alat dan Bahan}

Jenis penelitian ini adalah penelitian kuantitatif dengan bentuk eksperimen semu yang dilaksanakan pada bulan Juli sampai Agustus 2019 di SMPN 9 Palangka Raya. Design penelitian yang digunakan adalah design based research. Adapun penelitian ini melibatkan satu variabel bebas yaitu model PjBL $(X)$ dan dua variabel terikat $(Y)$ yaitu keterampilan proses sains dan sikap ilmiah siswa. Desain penelitian ini non-equivalent control group design dengan dua kelompok sampel, yakni kelas VIIlb sebagai kelompok eksperimen yang dibelajarkan dengan model PjBL dan kelas VIIlc sebagai kelompok kontrol yang dibelajarakan dengan metode konvensional. Kedua kelas tersebut dipilih sebagai sampel penelitian mengunakan teknik purposive sampling dengan pertimbangan kemampuan rata-rata siswa di antara dua kelas tersebut relatif sama atau homogen.

Data pada penelitian ini ada 3 jenis, yakni hasil belajar kognitif, keterampilan proses sains dan sikap ilmiah selama proses pembelajaran. Data hasil belajar kognitif dikumpulkan melalui tes objektif menggunakan instrumen soal pretest dan posttest yang berjumlah 15 pilihan ganda dan 5 soal pertanyaan diskusi. Data keterampilan proses sains yang diukur meliputi 4 indikator yaitu Mengamati, Menklasifikasi, Mengkomunikasikan, Menyimpulkan dan dikumpulkan melalui observasi dibantu oleh 3 observer yang telah dilengkapi dengan kisi-kisi sebagai instrument keterampilan proses sains (Sudjana, 2010). Data sikap ilmiah yang diukur meliputi 5 indikator yaitu Jujur, Teliti, Tanggung jawab, Rasa ingin tahu, Disiplin dan dikumpulkan melalui penyebaran angket kepada siswa

\subsection{Analisis Keterampilan Proses Sains}

Kriteria analisis menggunakan acuan sebagaimana disajikan pada Tabel 1.

Tabel 1. Skor indikator kategori keterampilan proses sains

\begin{tabular}{cc}
\hline Nilai & Kategori \\
\hline$<20$ & Sangat kurang \\
$21-40$ & Kurang \\
$41-60$ & Cukup \\
$61-80$ & Baik \\
$81-100$ & Sangat Baik \\
\hline
\end{tabular}

Sumber: Arifin (2013)

Data akan dianalisis dengan menggunakan analisis $\mathrm{N}$ gain yang bertujuan untuk mendeskripsikan peningkatan keterampilan proses sains berdasarkan data pretest dan posttest yang didapatkan. Data yang diperoleh akan dianalisis dengan menggunakan $\mathrm{N}$-gain ternormalisasi dengan rumus sebagai berikut:

$$
\mathrm{N} \text {-Gain }=\frac{\text { Skor posttest }- \text { skor pretest }}{\text { Skor maksimal }- \text { skor pretest }}
$$

Nilai kategori $\mathrm{N}$-gain yang diperoleh pada rumus tersebut dapat dilihat pada Tabel 2.

Tabel 2. Kategori N-Gain

\begin{tabular}{cc}
\hline Presentase (\%) & Kategori \\
\hline $0,7<<\mathrm{g}><1$ & Tinggi \\
$0,3<<\mathrm{g}><0,7$ & Sedang \\
$<\mathrm{g}><0,3$ & Rendah \\
\hline
\end{tabular}

Sumber: Ismarjiati dan Ishafit (2019)

\subsection{Analisis Sikap Ilmiah Siswa}

Untuk mengukur dan melihat sikap ilmiah pada siswa, peneliti menggunakan angket di kelas kontrol yang menggunakan pembelajaran konvensional dan kelas eksperimen menggunakan pembelajaran PjBL. Hasil pengambilan nilai angket dapat diklasifikasikan ke dalam beberapa golongan sebagaimana disajikan pada Tabel 3, dan skor dan rerata beda tiap indikator kategori sikap ilmiah siswa disajikan pada Tabel 4.

Tabel 3. Kategori nilai sikap ilmiah

\begin{tabular}{cc}
\hline Frekuensi & Kategori \\
\hline $20-49$ & Rendah \\
$50-79$ & Sedang \\
$80-100$ & Tinggi \\
\hline
\end{tabular}

Sumber: Arifin (2013) 
Tabel 4. Skor dan rerata beda tiap indikator kategori sikap ilmiah siswa

\begin{tabular}{cc}
\hline Frekuensi & Kategori \\
\hline $10-11$ & Rendah \\
$12-20$ & Sedang \\
$>21$ & Tinggi \\
\hline
\end{tabular}

Sumber: Arifin (2013)

Data akan dianalisis dengan menggunakan analisis $\mathrm{N}$ gain yang bertujuan untuk mendeskripsikan peningkatan sikap ilmiah siswa berdasarkan data pretest dan posttest yang didapatkan. Data yang diperoleh akan dianalisis dengan menggunakan $\mathrm{N}$-gain ternormalisasi dengan rumus berikut:

$$
\mathrm{N} \text {-Gain }=\frac{\text { Skor posttest }- \text { skor pretest }}{\text { Skor maksimal }- \text { skor pretest }}
$$

\section{HASIL DAN PEMBAHASAN}

\subsection{Keterampilan Proses Sains}

Kemampuan keterampilan proses sains siswa diperoleh dengan menggunakan rubrik penilaian. Rerata kedua kelas untuk tiap indikator keteranpilan proses sains disajikan pada Tabel 5.

Berdasarkan Tabel 5, pada kelas eksperimen nilai rerata ke empat indikator keterampilan proses sains termasuk ke dalam kategori tinggi, sedangkan pada kelas kontrol ke empat indikator termasuk ke dalam kategori cukup. Pada kelas eksperimen, indikator menyimpulkan memiliki nilai tertinggi yaitu 95,71. Hal ini dikarenakan pada saat kegiatan di kelas siswa memperhatikan dengan baik terbukti pada akhir pembelajaran siswa dapat menyimpulkan dengan baik dan tepat sesuai dengan arahan guru dan tujuan pembelajaran.

Berdasarkan pada Tabel 5, tiap indikator mempunyai total yang berbeda-beda dari dua kelas. Total pada tiap indikator menyentuh 2 kali lipat antara kelas eksperimen dan kelas kontrol. Hal ini disebabkan karena penggunaan model PjBL memiliki keunggulan yaitu mampu meningkatkan motivasi siswa, meningkatkan keterampilan siswa dalam mengelola sumber belajar yang tersedia, meningkatkan kolabarasi alamiah antar siswa dalam mengerjakan proyek yang telah direncenakan dan mampu memecahkan masalah komplek selama mengerjakan proyek. Selain itu siswa juga dapat meningkatkan kemampuan siswa dalam berkomunikasi antar sesama siswa dan guru, dan dapat menyimpulkan hasil kegiatan diskusi dengan baik secara lisan di depan kelas.

Jumlah nilai siswa dan rerata keterampilan proses sains siswa disajikan pada Tabel 6.

Berdasarkan Tabel 6, jumlah nilai keterampilan proses sains siswa pada kelas eksperimen materi jaringan tumbuhan menunjukkan nilai yang relatif tinggi dibandingkan jumlah nilai dan rerata pada kelas kontrol. Sehingga Tabel 6 menunjukkan bahwa keterampilan proses sains siswa dapat diimplementasikan dengan baik oleh model pembelajaran PjBL. Kelas eksperimen juga relatif lebih tinggi dibandingkan kelas kontrol. Hal ini terjadi karena pada kelas eksperimen siswa diberi kesempatan untuk ikut berperan dan berkarya dalam proses pembelajaran. Jelas bahwa model pembelajaran PjBL mendorong peserta didik untuk belajar berkarya dalam membuat sebuah proyek dan siswa menjadi lebih aktif, artinya siswa diajak untuk ambil bagian tentang menemukan sebuah ide yang kreatif dan inovatif dengan cara mereka sendiri dan berlatih menyelesaikan proyek tersebut dengan menggunakan keterampilan pengetahuannya sehingga pengetahuan dan pengalaman belajar mereka akan tertanam untuk jangka waktu yang cukup lama (Goodman, 2008).

Tabel 5. Total tiap indikator KPS siswa

\begin{tabular}{lllc}
\hline \multicolumn{1}{c}{ Indikator } & \multicolumn{1}{c}{ Kelas } & Total & Kategori \\
\hline \multirow{2}{*}{ Mengamati } & Kelas Kontrol & 49,28 & Cukup \\
& Kelas Eksperimen & 83,28 & Tinggi \\
Mengklasifikasi & Kelas Kontrol & 48,57 & Cukup \\
& Kelas Eksperimen & 88,57 & Tinggi \\
Mengkomunikasikan & Kelas Kontrol & 47,14 & Cukup \\
\multirow{2}{*}{ Menyimpulkan } & Kelas Eksperimen & 90,71 & Tinggi \\
& Kelas Kontrol & 45,71 & Cukup \\
\hline
\end{tabular}

Tabel 6. Jumlah nilai siswa dan rerata keterampilan proses sains siswa

\begin{tabular}{cccc}
\hline Perlakuan & Jumlah Siswa & Jumlah Nilai Rerata Siswa & Rerata \\
\hline Kelas Kontrol & 28 & 58.5 & 2.09 \\
Kelas Eksperimen & 28 & 127.5 & 4,553 \\
\hline
\end{tabular}


Hasil analisis Keterampilan Proses Sains menggunakan N-Gain secara ringkas disajikan dalam Tabel 7.

Tabel 7. Hasil Analisis Ngain keterampilan proses sains

\begin{tabular}{ccc}
\hline Kelas & N-Gain & Kategori \\
\hline Kelas Eksperimen & $\mathbf{0 , 7 0}$ & Tinggi \\
Kelas Kontrol & $\mathbf{0 , 4 7}$ & Sedang \\
\hline
\end{tabular}

Berdasarkan hasil perhitungan uji N-gain diatas yang dianalisis dengan Microsoft Excel, menunjukkan bahwa nilai rata-rata $\mathrm{N}$-gain untuk kelas eskperimen sebesar 0,70 dan termasuk dalam kategori Tinggi. Nilai ini lebih tinggi dibandingkan dengan nilai $\mathrm{N}$-gain untuk kelas kontrol sebesar 0,47 dan termasuk dalam kategori Sedang. Hal ini menunjukkan setelah diterapkan pembelajaran menggunakan model pembelajaran PjBL terjadi peningkatan terhadap keterampilan proses sains.

Berdasarkan Tabel 7, total skor nilai dan rerata keterampilan proses sains siswa pada kelas eksperimen materi jaringan tumbuhan menunjukkan nilai yang tinggi dari pada jumlah nilai dan rerata dari kelas kontrol. Hal ini karena pada saat menggunakan pembelajaran $\mathrm{PjBL}$ yang berbasis proyek siswa dapat melihat langsung dan mengamati secara langsung serta berperan aktif dalam pembuatan proyek yang diarahkan oleh guru (Indarti dan Purwantoyo, 2017). Pada kelas kontrol yang nilainya lebih rendah dibandingkan kelas eksperimen, hal ini disebabkan karena siswa tidak bisa mengamati secara langsung dan tidak ikut berperan aktif secara langsung dan hanya mengandalkan penjelasan guru mengenai materi jaringan pada tumbuhan. Berdasarkan Tabel 1, skor terendah indikator keterampilan proses sains siswa pada kelas eksperimen yaitu pada indikator mengamati yaitu 83,28. Hal Ini disebabkan karena pada saat pembelajaran siswa tidak dapat mengamati dengan baik dan konsisten bahan pembuatan proyek dengan benar pada materi jaringan tumbuhan yang diketahui berdasarkan tujuan pembelajaran. Perhatian siswa dalam mengamati materi dengan baik mempengaruhi ingatan siswa dalam meyimpulkan materi pembelajaran dengan baik (Maulidiyah, 2011). Berdasarkan tabel 6 skor tertinggi indikator keterampilan proses sains siswa pada kelas eksperimen yaitu pada indikator menyimpulkan yaitu 95,71.

\subsection{Sikap Ilmiah}

Sikap ilmiah siswa diperoleh dengan menggunakan angket. Angket ini di ujikan pada awal pembelajaran untuk mengetahui kemampuan sikap ilmiah yang dimiliki oleh siswa sebelum di berikan perlakuan model PjBL serta pada akhir pembelajaran penelitian untuk mengetahui hasil peningkatan sikap ilmiah yang telah diperoleh. Hasil yang menunjukkan perbedaan sikap ilmiah siswa pada kelas konrol dan eksperimen berupa skor dan rerata beda tiap indikator dapat dilihat pada Tabel 8.

Berdasarkan pada Tabel 8, hasil pretest sikap ilmiah rerata pada 2 kelas yang terbagi antara kelompok kontrol dan eksperimen tidak banyak perbedaan yang mencolok dimana rerata terbesar terdapat pada indikator disiplin kelas eksperimen yaitu sebesar 25,93 dan yang terkecil pada indikator rasa ingin tahu kelas kontrol yaitu sebesar 12,14. Hal ini disebabkan rerata sikap ilmiah tersebut merupakan hasil dari sistem pembelajaran terdahulu yang telah terlaksana pada 2 kelas sebelum perlakuan diberikan.

Sementara itu, hasil posttest rerata pada kelas kontrol dan eksperimen dapat dilihat pada Tabel 9.

Berdasarkan pada Tabel 9, nilai angket posttest tertinggi pada kelas eksperimen pada indikator disiplin dengan rerata 36.93 dan terendah pada indikator rasa ingin tahu dengan rerata sebesar 19,67. Berdasarkan hasil data tersebut terdapat perbedaan skor rerata yang berbeda antara kelas kontrol yang memakai model pembelajaran biasa dan kelas eksperimen yang memakai model PjBL dengan rentang nilai terkecil selisih 3 angka pada indikator tanggung jawab dan rentang nilai terbesar dengan selisih 12 angka pada indikator disiplin.

Hasil analisis sikap ilmiah menggunakan N-Gain pada kedua kelas dapat secara ringkas disajikan pada Tabel 10.

Tabel 8. Rerata tiap indikator pretest sikap ilmiah siswa

\begin{tabular}{llcc}
\hline \multicolumn{1}{c}{ Indikator } & \multicolumn{1}{c}{ Kelas } & Rerata & Kategori \\
\hline \multirow{2}{*}{ Jujur } & Kelas Kontrol & 13.18 & Sedang \\
& Kelas Eksperimen & 18.18 & Sedang \\
Teliti & Kelas Kontrol & 14.50 & Sedang \\
& Kelas Eksperimen & 15.75 & Sedang \\
Tanggung Jawab & Kelas Kontrol & 14.82 & Sedang \\
& Kelas Eksperimen & 14.11 & Sedang \\
Disiplin & Kelas Kontrol & 22.75 & Tinngi \\
& Kelas Eksperimen & 25.93 & Tinggi \\
Rasa Ingin Tahu & Kelas Kontrol & 12.14 & Sedang \\
& Kelas Eksperimen & 13.64 & Tinggi \\
\hline
\end{tabular}


Tabel 9. Rerata tiap indikator posttest sikap ilmiah siswa

\begin{tabular}{llcc}
\hline \multicolumn{1}{c}{ Indikator } & \multicolumn{1}{c}{ Kelas } & Rerata & Kategori \\
\hline \multirow{2}{*}{ Jujur } & Kelas Kontrol & 24,14 & Tinggi \\
& Kelas Eksperimen & 28,75 & Tinggi \\
\multirow{2}{*}{ Teliti } & Kelas Kontrol & 23,82 & Tinggi \\
& Kelas Eksperimen & 28,54 & Tinggi \\
\multirow{2}{*}{ Tanggung Jawab } & Kelas Kontrol & 23,50 & Sedang \\
& Kelas Eksperimen & 27,57 & Tinggi \\
\multirow{2}{*}{ Disiplin } & Kelas Kontrol & 24,57 & Sedang \\
& Kelas Eksperimen & 36,93 & Tinggi \\
\multirow{2}{*}{ Rasa Ingin Tahu } & Kelas Kontrol & 13,92 & Sedang \\
& Kelas Eksperimen & 19,67 & Sedang \\
\hline
\end{tabular}

Tabel 10. Hasil analisis N-Gain sikap ilmiah

\begin{tabular}{ccc}
\hline Kelas & N-Gain & Kategori \\
\hline Kelas Eksperimen & $\mathbf{0 , 5 8}$ & Sedang \\
Kelas Kontrol & $\mathbf{0 , 3 2}$ & Sedang \\
\hline
\end{tabular}

Berdasarkan hasil perhitungan uji N-gain diatas yang dianalisis dengan Microsoft Excel, menunjukkan bahwa nilai rata-rata N-Gain untuk kelas eskperimen sebesar 0,58 dan termasuk dalam kategori Sedang. Nilai ini lebih termasuk dalam kategori Sedang. Maka kesimpulannya adalah model PjBL tidak meningkatkan sikap ilmiah siswa

Berdasarkan Tabel 9, terlihat tidak adanya perbedaan skor rerata antara 5 indikator yang mewakili kelompok kontrol dan eksperimen,yaitu menggunakan model PjBL dengan sikap siswa yang menggunakan model pembelajaran konvensional. Data menunjukkan sikap siswa pada kelas eksperimen lebih tinggi dibandingkan sikap siswa pada kelas kontrol, ini disebabkan karena pada saat pembelajaran berlangsung menggunakan model PjBL kelas eskperimen membuat proyek yang dalam prosesnya siswa bersosialisasi dengan baik dengan teman sekelompoknya sehingga peneliti bisa mengamati sikap siswa yang termasuk dalam lima indikator yang diamati. Pada kelas kontrol peneliti kesulitan dalam mengamati sikap siswa karena siswa belajar dengan model pembelajaran konvensional dan siswa tidak bergerak secara aktif seperti yang dilakukan di kelas eksperimen.

Berdasarkan Tabel 9, skor terendah indikator sikap ilmiah siswa pada kelas kontrol yaitu pada indikator rasa ingin tahu. Ini disebabkan karena siswa pada beberapa kelompok praktikum terkesan acuh tak acuh pada proses pembelajaran yang peneliti berikan sehingga banyak kesalahan dan kekeliriuan pada saat merencanakan langkah kegiatan proyek. Penyebab utama saat ditanyakan adalah jam pelajaran MIPA yang pada konsepnya memerlukan tingkat kognitif tinggi seringkali di laksanakan pada jam-jam siang dimana seringkali pada pelajar merasa mengantuk dan hanya memperhatikan tanpa mengerti apa yang sedang di ajarkan oleh guru di depan. Akibatnya pada saat pengerjaan proyek, sebagian kelompok ada yang tertinggal dari kelompok lain sehingga memerlukan perhatian ekstra dan waktu yang dibutuhkan untuk menyelesaikan proyek tepat waktu semakin tertunda. Berdasarkan tabel 9 skor tertinggi indikator sikap ilmiah siswa pada kelas eksperimen yaitu pada indikator Disiplin. Ini disebabkan karena siswa tepat waktu dalam menyelesaikan proyek sesuai waktu yang ditentukan oleh guru juga diterapkan sistem sanksi berjenjang yaitu sanksi ringan yaitu menyanyi di depan kelas, serta sanksi yang berat yaitu membantu membersihkan kelas seusai jam belajar sekolah. Sikap disiplin adalah sikap terpenting dalam sikap ilmiah karena sikap ini adalah sikap yang harus dimiliki oleh peneliti dalam melakukan sebuah penelitian dasar (Hermayani et al., 2015).

Hasil analisis perhitungan N-Gain skor pada Tabel 10 menunjukkan tidak terdapat perbedaan antara kelompok kontrol dan kelompok eksperimen. Hal ini terbukti dengan hasil perhitungan $\mathrm{N}$-gain skor kelompok kontrol sebesar 0,32 yang termasuk dalam kategori sedang dan hasil perhitungan $\mathrm{N}$-Gain skor kelompok eksperimen yang hanya naik sebesar 0,27 angka menjadi 0,58 yang juga dalam kategori sedang. Hal ini disebabkan karena sikap ilmiah yang dimiliki peserta didik merupakan hasil warisan proses belajar mengajar terdahulu yang mengedepankan model pembelajaran konvensional sehingga dibutuhkan proses waktu yang berkelanjutan dalam memakai model pembelajaran $\mathrm{PjBL}$ untuk mencapai standar indikator yang diinginkan. Berdasarkan hasil data rekapitulasi yang digunakan untuk menilai keterampilan proses sains pada pelaksanaan model PjBL dilakukan pada materi Jaringan Tumbuhan. Sikap ilmiah yang sering muncul yaitu disiplin, jujur dan bersikap teliti terhadap proyek yang dikerjakan bersama. Dimana hubungan dari Keterampilan Proses Sains dan Sikap IImiah didalam pengamatan yang dilakukan peneliti adalah sikap ilmiah sangat berpengaruh dalam Keterampilan Proses Sains yang ada pada peserta didik. 
Karena pembelajaran sains bukan hanya transfer ilmu namun sebuah proses yang memfasilitasi siswa unuk melatih keterampilan, membangun kemampuan kognitifnya dan menumbuhkan sikap positif (Trianto, 2017).

\section{PEMBAHASAN}

Berdasarkan pengamatan pada saat kegiatan pembelajaran berlangsung dan hasil wawancara dengan beberapa siswa, permasalahan tersebut muncul dikarenakan guru menggunakan metode yang kurang bervariasi yakni hanya dengan berceramah dan siswa kurang dilibatkan secara aktif dalam kegiatan pembelajaran. Proses pembelajaran konvensional menyebabkan kurangnya keaktifan belajar siswa pada mata pelajaran jaringan tumbuhan dan terkesan terburu-buru mengakibatkan siswa cenderung menjadi pasif dalam belajar, kurang menghargai guru dan teman, dan kurang memahami materi yang disampaikan.

Salah satu upaya untuk meningkatkan keaktifan belajar siswa di kelas adalah dengan melakukan perbaikan dalam proses pembelajaran. Guru sebagai pendidik dituntut untuk mengembangkan potensinya, salah satunya yakni dengan menerapkan metode pembelajaran yang inovatif dan dapat memotivasi sehingga keaktifan belajar siswa dapat meningkat. Kemampuan guru memberi motivasi kepada siswa untuk belajar akan memberi arti penting dalam proses pembelajaran. Tujuan pembelajaran sudah tercapai separuhnya jika guru mampu memberi motivasi kepada peserta belajar. Guru cukup mengekplorasi kemampuan yang dimiliki peserta belajar dan memadukan bersama motivasinya untuk mecapai target pembelajaran sesuai dengan yang diharapkan (Munirah, 2018)

Selain itu, guru juga harus memahami faktor-faktor yang dapat mempengaruhi belajar peserta didik (Sukmadinata, 2019). Pertama, faktor internal yaitu faktor yang berasal dari dalam diri peserta didik seperti kondisi psikologi dan kondisi fisiologi peserta didik. Kedua, faktor eksternal yaitu faktor yang berasal dari lingkungan, desain pembelajaran dan seterunsnya.

\subsection{Keterampilan Proses Sains Siswa}

Berdasarkan Tabel 6, total skor nilai dan rerata keterampilan proses sains siswa pada kelas eksperimen materi jaringan tumbuhan menunjukkan nilai yang tinggi dari pada jumlah nilai dan rerata dari kelas kontrol. Hal ini karena pada saat menggunakan pembelajaran $\mathrm{PjBL}$ yang berbasis proyek siswa dapat melihat langsung dan mengamati secara langsung serta berperan aktif dalam pembuatan proyek yang diarahkan oleh guru. Pada kelas kontrol yang nilainya lebih rendah dibandingkan kelas eksperimen, hal ini disebabkan karena siswa tidak bisa mengamati secara langsung dan tidak ikut berperan aktif secara langsung dan hanya mengandalkan penjelasan guru mengenai materi jaringan pada tumbuhan. Berdasarkan
Tabel 5, skor terendah indikator keterampilan proses sains siswa pada kelas eksperimen yaitu pada indikator mengamati yaitu 83,28. Hal Ini disebabkan karena pada saat pembelajaran siswa tidak dapat mengamati dengan baik dan konsisten bahan pembuatan proyek dengan benar pada materi jaringan tumbuhan yang diketahui berdasarkan indikator silabus. Perhatian siswa dalam mengamati materi dengan baik mempengaruhi ingatan siswa dalam meyimpulkan materi pembelajaran dengan baik pula. Berdasarkan Tabel 5 skor tertinggi indikator keterampilan proses sains siswa pada kelas eksperimen yaitu pada indikator menyimpulkan yaitu 95,71. Ini sependapat dengan pendapat Dimyati dan Mudjiono (2009) menyatakan bahwa kemampuan dalam menyimpulkan hipotesis merupakan langkah penting yang harus dimiliki seorang siswa. Keterampilan dalam menyimpulkan hipotesis menghasilkan rumusan dalam bentuk kalimat pernyataan berupa dugaan yang dianggap benar dan dibuktikan dalam pengamatan. Kemampuan siswa dalam menyimpulkan hipotesis masih perlu dilatih dan dibiasakan supaya siswa bisa lebih tepat dalam menyusun hipotesis sesuai dengan masalah yang diajukan.

Semiawan dalam (Hamalik, 2006) menjelaskan bahwa dengan mengembangkan keterampilan proses sains, siswa akan mampu menemukan dan mengembangkan sendiri fakta dan konsep serta menumbuhkan dan mengembangkan sikap dan nilai yang dituntut. Keterampilan itu sendiri menjadi roda penggerak penemuan dan pengembangan fakta dan konsep serta penumbuhan dan pengembangan sikap dan nilai.

Hasil penelitian menunjukkan bahwa setelah dibelajarkan dengan menggunakan model pembelajaran PjBL materi jaringan tumbuhan pada siswa kelas VIII SMP Negeri 9 Palangka Raya dapat meningkatkan keterampilan proses sains. Hal ini karena pada nilai rata-rata $\mathrm{N}$-gain skor untuk kelas eskperimen sebesar 0.70 termasuk dalam kategori tinggi dibandingkan dengan rata-rata $\mathrm{N}$-gain skor kelas kontrol sebesar 0,47 yang termasuk dalam kategori sedang. Meningkatnya keterampilan proses sains pada materi jaringan tumbuhan karena adanya kecocokan karakteristik materi jaringan tumbuhan dengan model pembelajaran PjBL. Hal ini dapat dilihat berdasarkan karakteristik pembelajaran PjBL yang berbasis proyek yang menuntut siswa melakukan proyek dan pada materi jaringan tumbuhan siswa diminta secara bersama-sama untuk mengamati dan mengidentifikasi struktur dan fungsi tumbuhan serta teknologi yang terinspirasi oleh struktur tumbuhan dan menyusun rencana dan melakukan percobaan berdasarkan hasil pengamatan, diharapkan siswa benar-benar memahami materi jaringan tumbuhan sebagai upaya meningkatkan keterampilan dan sikap dalam kehidupan sehari-hari. Kelebihan model pembelajaran $\mathrm{PjBL}$ terfokus pada keterlibatan siswa untuk belajar secara aktif, dengan demikian siswa tidak hanya menerima saja materi pengajaran yang diberikan guru, melainkan siswa juga berusaha menggali dan mengembangkan sendiri dalam kelompok belajarnya 
melalui proyek yang dilakukan. Ini sejalan dengan pendapat Anshori (2018) PjBL merupakan pengembangan kurikulum dan sistem pengajaran yang mengembangkan secara stimulan strategi pemecahan masalah dan dasardasar pengetahuan dan keterampilan dengan menempatkan para siswa dalam peran aktif dalam bentuk pemecah permasalahan sehari-hari yang tidak terstruktur dengan benar.

\subsection{Sikap Ilmiah Siswa}

Hasil analisis data N-Gain pada aspek sikap ilmiah pada Tabel 6 tidak menunjukan adanya perbedaan skor rerata antara 5 indikator yang mewakili kelompok kontrol dan eksperimen,yaitu menggunakan model PjBL dengan sikap siswa yang menggunakan model pembelajaran konvensional. Data menunjukkan sikap siswa pada kelas eksperimen lebih tinggi dibandingkan sikap siswa pada kelas kontrol, ini disebabkan karena pada saat pembelajaran berlangsung menggunakan model PjBL kelas eskperimen membuat proyek yang dalam prosesnya siswa bersosialisasi dengan baik dengan teman sekelompoknya sehingga peneliti bisa mengamati sikap siswa yang termasuk dalam lima indikator yang diamati. Sedangkan pada kelas kontrol peneliti kesulitan dalam mengamati sikap siswa karena siswa belajar dengan model pembelajaran konvensional dan siswa tidak bergerak secara aktif seperti yang dilakukan di kelas eksperimen dan hanya menunggu penjelasan dari guru di depan kelas saja. Sehingga diperlukan upaya berkelanjutan untuk membiasakan pendidik dan peserta didik agar memperoleh sikap ilmiah yang optimal sehingga dapat meningkatkan kemampuan afektif siswa menjadi lebih baik. Karena pembelajaran sains bukan hanya transfer ilmu namun sebuah proses yang memfasilitasi siswa unuk melatih keterampilan, membangun kemampuan kognitifnya dan menumbuhkan sikap positif. .

Berdasarkan Tabel 10, skor terendah indikator sikap ilmiah siswa pada kelas kontrol yaitu pada indikator rasa ingin tahu. Ini disebabkan karena siswa pada beberapa kelompok praktikum terkesan acuh tak acuh pada proses pembelajaran yang peneliti berikan sehingga banyak kesalahan dan kekeliriuan pada saat merencanakan langkah kegiatan proyek. Penyebab utama saat ditanyakan adalah jam pelajaran MIPA yang pada konsepnya memerlukan tingkat kognitif tinggi seringkali di laksanakan pada jam-jam siang dimana seringkali pada pelajar merasa mengantuk dan hanya memperhatikan tanpa mengerti apa yang sedang di ajarkan oleh guru di depan. Akibatnya pada saat pengerjaan proyek, sebagian kelompok ada yang tertinggal dari kelompok lain sehingga memerlukan perhatian ekstra dan waktu yang dibutuhkan untuk menyelesaikan proyek tepat waktu semakin tertunda. Berdasarkan tabel 10 skor tertinggi indikator sikap ilmiah siswa pada kelas eksperimen yaitu pada indikator Disiplin. Ini disebabkan karena siswa tepat waktu dalam menyelesaikan proyek sesuai waktu yang ditentukan oleh guru juga diterapkan sistem sanksi berjenjang yaitu sanksi ringan yaitu menyanyi di depan kelas, serta sanksi yang berat yaitu membantu membersihkan kelas seusai jam belajar sekolah. Sikap disiplin adalah sikap terpenting dalam sikap ilmiah karena sikap ini adalah sikap yang harus dimiliki oleh peneliti dalam melakukan sebuah penelitian dasar tanpa mengambil karya orang lain (Marjono, 2015).

Hasil analisi perhitungan N-Gain skor pada Tabel 10 menunjukkan tidak terdapat perbedaan antara kelompok kontrol dan kelompok eksperimen. Hal ini disebabkan karena sikap ilmiah yang dimiliki peserta didik merupakan hasil warisan proses belajar mengajar terdahulu yang mengedepankan model pembelajaran konvensional sehingga dibutuhkan proses waktu yang berkelanjutan dalam memakai model pembelajaran PjBL untuk mencapai standar indikator yang diinginkan. Berdasarkan hasil data rekapitulasi yang digunakan untuk menilai keterampilan proses sains pada pelaksanaan model PjBL dilakukan pada materi Jaringan Tumbuhan. Sikap ilmiah yang sering muncul yaitu disiplin, jujur dan bersikap teliti terhadap proyek yang dikerjakan bersama. Dimana hubungan dari Keterampilan Proses Sains dan Sikap Ilmiah didalam pengamatan yang dilakukan peneliti adalah sikap ilmiah sangat berpengaruh dalam Keterampilan Proses Sains yang ada pada peserta didik. Karena pembelajaran sains bukan hanya transfer ilmu namun sebuah proses yang memfasilitasi siswa untuk melatih keterampilan, membangun kemampuan kognitifnya dan menumbuhkan sikap positif

\section{KESIMPULAN}

1. Model pembelajaran $\mathrm{PjBL}$ dapat meningkatkan keterampilan proses sains pada materi jaringan tumbuhan di SMP Negeri 9 Palangka Raya. Dengan nilai rata-rata $\mathrm{N}$-gain skor untuk kelas eskperimen sebesar 0.70 yang termasuk dalam kategori tinggi dan $\mathrm{N}$-gain skor pada kelas kontrol sebesar 0.47 pada kategori sedang.

2. Model pembelajaran PjBL tidak meningkatkan sikap ilmiah di SMP Negeri 9 Palangka Raya. Dibuktikan dengan hasil analisis menggunakan $\mathrm{N}$-gain dengan jumlah skor $\mathrm{N}$-gain pada kelas kontrol adalah dengan sebesar 0.32 sedangkan $\mathrm{N}$-gain pada kelas eksperimen adalah 0.58. Keduanya termasuk dalam kategori sedang.

\section{UCAPAN TERIMA KASIH}

Penulis mengucapkan terima kasih yang sebesar-besarnya kepada Program Pascasarjana Universitas Palangka Raya 
yang mendukung sepenuhnya penelitian ini. Tidak lupa ucapan terima kasih untuk Kepala Sekolah SMPN 9 Palangka Raya dan guru pemangku bidang studi, serta pihak-pihak lain yang sudah banyak membantu dan memberikan kesempatan penulis untuk meneliti di sekolah tersebut.

\section{DAFTAR PUSTAKA}

Anshori, A., 2018. 68 Model Pembelajaran Inovatif dalam Kurikulum 2013. Arruzz Media. Yogyakarta.

Arifin. 2013. Evaluasi Pembelajaran. PT. Remaja Rosdakarya. Bandung.

Biggs, J., 2010. Definisi Belajar. Surya Kencana. Bandung.

Dimyati dan Mudjiono. 2009. Belajar dan Pembelajaran. Rineka Cipta. Jakarta.

Goodman, D., 2008. Problem-based learning in the MPA curriculum. Journal of Public Affairs Education, 14(2), 253-270.

Hermayani, A.Z., Dwiastuti, S. and Marjono, M., 2015. Peningkatan Motivasi Belajar Dan Kemampuan Berpikir Kritis Siswa Pada Materi Ekosistem Melalui Penerapan Model Inkuiri Terbimbing. BIOEDUKASI, 6(2), 79-85.

Indarti, I. and Purwantoyo, E., 2017. Keefektifan Project Based Learning dengan Observasi pada Materi
Keanekaragaman Tumbuhan Tingkat Tinggi. Journal of Biology Education, 6(2), 187-194.

Ismarjiati, N. and Ishafit, I.,2019. Implementasi Projects Based Learning Pada Pokok Bahasan Titik Berat di Kelas XI SMA. Jurnal Materi dan Pembelajaran Fisika, 9(2), 103 $-107$.

Kemendikbud. 2017. Materi Pelatihan Buku Guru Ilmu Pengetahuan Sosial 2017. Badan Pengembangan Sumber Daya Manusia Pendidikan dan Kebudayaan dan Penjaminan Mutu Pendidikan Kementerian Pendidikan dan Kebudayaan

Munirah, M., 2018. Prinsip-Prinsip Belajar dan Pembelajaran (Perhatian, Motivasi, Keaktifan, Keterlibatan langsung, Pengulangan, Tantangan, dan Perbedaan Individu). Auladuna: Jurnal Pendidikan Dasar Islam, 5(1), 116-125.

Ngalimun. 2014. Strategi dan Model Pembelajaran. Aswaja Pressindo. Yogyakarta.

Hamalik, O., 2006. Manajemen pengembangan kurikulum. Sekolah Pascasarjana Universitas Pendidikan Indonesia dengan PT Remaja Rosdakarya.

Sudjana. 2010. Instrumen Penilaian Keterampilan Proses Sains. Tarsito. Bandung.

Sukmadinata, N.S., 2019. Landasan psikologi proses pendidikan. Bandung: PT. Remaja Rosdakarya

Trianto. 2017. Penerapan Model Pembelajaran PjBL. Sinar Biru. Bandung. 